\title{
Private assistance in the National Health System
}

\author{
La asistencia privada en el Sistema Nacional de Salud
}

Jaime Lozano-Alcázar*

Academician emeritus, former president of the Mexican Academy of Surgery, medical director of Fundación Hospital Nuestra Señora de la Luz, Mexico City, Mexico

Frequently, in conferences, sessions and in general health statistics in Mexico, including the contributions of private assistance institutions is omitted.

In the colonial period, the Catholic Church was the entity dedicated par excellence to social activities. Religious orders, while spreading their evangelizing mission, were founding schools, hospices, nursing homes and hospitals. However, already since the $16^{\text {th }}$ century, assistance foundations started being installed in the New Spain. Many of these institutions were independent of the will of the clergy's hierarchy, and were therefore not strictly linked to the Church, although they were usually served by religious monastic orders that were gradually settling in the conquered territory.

That which is defined as the first assistance institution founded in the country is due to the wishes of conqueror Hernán Cortés, who assigned the funds for its foundation, which was carried out in 1524, just 3 years after the fall of Tenochtitlan'. It is the Hospital de la Inmaculada Concepción de Nuestra Señora y de Jesús Nazareno, which survives to this day and is known as Hospital de Jesús, which retains its original location at number 82 of current 20 de Noviembre Avenue, in Mexico City's downtown, according to the traditional version, at the site of the first meeting between the Extremaduran and Moctezuma II. The testamentary will emphasized that it would be dedicated to the wounded during the war of conquest and to the care of the children of those fallen in the defense of the Aztec capital city².
Dr. Pedro López, a physician graduated from the University of Valladolid (Castile, Spain), whose degree would later be validated by the University of Mexico, which subsequently awarded him a doctorate after hard efforts managed to have the means to found the St. Lazarus Hospital in 1572, dedicated to patientš affected by leprosy, the first of its kind in the continent, and in 1582, the Hospital for the Underprivileged

Dr. Lopez was a friend of Friar Bernardino Álvarez, another enthusiastic creator of hospitals. He founded the St. Hippolytus of Charity order, better known as Hipólitos, dedicated to the care of dementia patients. In the convent annexed to St. Hippolytus temple, which he ordered to build, at the Puente de Alvarado avenue in Mexico City, Friar Bernardino installed in 1566 America's first hospital dedicated to alienated people? In 1586 he founded in Oaxtepec, in current Morelos State, the Hospital de Santa Cruz, also for the mentally ill,ând he did not stop there, but continued his benevolent work by founding hospitals in Acapulco, Puebla, Xaläpa and even La Havana ${ }^{3.4}$. Friar Bernardino also practiced medicine.

Throughout the colonial period, especially ingthe $16^{\text {th }}$ and $17^{\text {th }}$ centuries, other secular hospitals continued to be founded thanks to the contributions of corporations, such as Hospital de San Juan de Letrán in Puebla, Hospital de Nuestra Señora de los Remedios in Campeche, Hospital de Nuestra Señora del Rosario in Mérida, Hospital de la Caridad del Nombre de Gios in Durango, Hospital de la Santa Veracruz in Valladelid, Yucatán, Hospital de Nuestra Señora de Montserrat in

\footnotetext{
Correspondence:

*Jaime Lozano-Alcázar

Pestalozzi 1204-803,

Col. del Valle, Del. Benito Juárez,

C.P. 03100 , Mexico City, Mexico

E-mail: drjaimelozano@gmail.com
}

Date of reception: 17-05-2018

Date of acceptance: 30-05-2018

DOI: 10.24875/CIRUE.M18000057
Cir Cir. 2018;86:336 338

Contents available at PubMed www.cirugiaycirujanos.com 
Mexico City and Hospital de San Cosme y San Damian in Veracruz, just to mention a few ${ }^{3}$. The last hospital created during the colonial period was Hospital de San Sebastian, in 1799, in the city of Veracruz ${ }^{5}$.

With the passing of time, these hospitals had dissimilar destinies: some disappeared, others preserve their name and vocation, and others received a new secular name after the liberal reforms. A well-known example is current Juarez Hospital, born as Hospital de San Pablo, given that the old College of St. Paul of the Augustinians was transformed into a hospital to respond to the needs imposed by the war against the US in 1847.

As we can see, to that first private assistance institution, Hospital de Jesus, other philanthropic institutions especially concerned for the population in vulnerable conditions were gradually added; in fact, Don Valentín Gómez Farias, in 1833, while being President of the Republic, tried to create a health assistance system to take care of the poorest population'.

The Law for the Confiscation of Rustic and Urban Properties owned by Civil and Religious Corporations, known as the Lerdo Act and promulgated in 1856 by Ignacio Comonfort as president of the Republic, as well as the set of ordinances called the Reform Laws, drove the Church to stop managing numerous assistance institutions, with most part of the responsibility for public assistance being left in the hands of the State. The government of the Republic did not stray from the needs of the population; President Benito Juarez, in 1861, created the General Directorate for Charitable Funds, which, exempted from taxes, could exclusively be invested in charitable works. Public Welfare was assigned to the Federal District Government'.

To improve the control and functions of the charity institutions, as well as to prevent fraudulent situations, General Porfirio Díaz, on November 7, 1899, promulgated the Law of Private Assistance Institutions for the Federal District with the purpose to support, promote and protect the initiatives of private citizens in favor of the most needy. In that law, the creation of the Private Assistance Board (JAP - Junta de Asistencia Privada) was established, which monitors the sound operation of private assistance institutions in Mexico City. The different institutions sheltered in the JAP are grouped into six areas: 1) Education, culture and community development; 2) Girls, boys and adolescents; 3) The elderly; 4) Disability and rehabilitation; 5) Health and addictions; and 6) Donors and pawnbrokers. The area of Health and addictions is composed of 81 institutions, including Beneficencia Española, Escandón Hospital, the Mexican Red Cross, Hospital de Jesús and F̂ne American British Cowdray Medical Center, just to mention a few'.

In that sector of private assistance institutions dedicated to health and addictions, there are three hospitals for the care of patients with eye conditions, which \& will refer to given that ophthalmology is my specialty and because I know better their scope and functioning: In order of seniority, the Fundación Hospital Nuestra Señora de la Luz I.A.P., born in 1876 by the testamentary legacy of Don Ignacio Valdivielso y Vidal de Lorca, तifth count of San Pedro del Álamo; the Association to Prevent Blindness in Mexico, I.A.P., founded in 1918 by a group of philanthropists led by Dr. José Terrés; and Conde de Valenciana Foundation, Institute of Ophthalmolëgy, founded in 1976, thanks to the inheritance left by. Đon Luis Ludert y Rull, Count of La Valenciana. All three institutions kindly provided the data that I mention below.

Only last year, 2017, overall, physicians from these three institutions dedicated to ophthalmology carried out, in round figures, 440,000 specialty consultations, 31,000 ophthalmological surgeries and 60,000. eye treatments (laser procedures, intravitreal injectiōns, etc.), in addition to 60,000 consultations from other specialties (cardiology, internal medicine, immunology, etc.) in their auxiliary services. These three hospitals are estimated to provide $50 \%$ of ophthalmological care to the Mexican population.

In my opinion, the above-mentioned figures speak by themselves regarding the importance of these three institutions for the country's visual health. Furthermore, if to these figures the hundreds of thousands more of patients who are cared for at different private assistance health institutions are added, the highly important contribution they make to the National Health System becomes evident, which, as I previously mentioned, appears to be rarely recognized in official statisfics. Moreover, most private assistance institutions preserve the altruistic vocation that gave them origin and proyide care to financially vulnerable patients, or have health assistance programs as part of their activities; witt no doubt, the social work they develop is highly significant. We can just imagine the chaos that would cause to- our social security and protection systems, already saturated, if all these patients would demand their services, all the more so if we consider that, according to the May 29, 2018 Forbes Mexico website, data from the National Institute of Statistics and Geography (INEGI - Instituto Nacional de Geografía y Estadística) indiceate that, out of the 112.33 million Mexicans, only $10 \%$ have access to $41.7 \%$ of the resources generated by the 
country annually ${ }^{6}$; i.e., only a minor proportion of Mexicans can afford private medical care, and the rest must resort to State social security systems or private assistance institutions. Private medicine and private assistance health institutions are indispensable pillars of our National Health System.

\section{References}

1. Junta de Asistencia Privada del Distrito Federal (Consultado el 29/05/18) Disponible en: http://jap.org.mx/portal/index.php?lang=es
2. Hospital de Jesús Nazareno. Wikipedia (Consultado el 29/05/18) Disponible en: https://en.wikipedia.org/wiki/Hospital_de_Jesús_Nazareno

3. Rodríguez-Sala ML, Ramírez V, Tolentino A, Rivera C, Pérez A, Mireles A. Los cirujanos de hospitales de la Nueva España (siglos XVI y XVII): ¿miembros de un estamento profesional o de una comunidad científica? Universidad Nacional Autónoma de México, Instituto de Investigaciones Sociales, Academia Mexicana de Cirugía, Patronato del Hospital de Jesús, Secretaría de Salubridad y Asistencia. 1. ${ }^{a}$ ed. 2005.

4. Bernardino Álvarez. Wikipedia (Consultado el 29/05/18) Disponible en: https://commons.wikimedia.org/wiki/Category:Bernardino_Álvarez

5. Loyo-Varela M, Díaz-Cházaro $H$. Hospitales en México. Cir Cir. 2009;77:497-504.

6. Baltasar Madrid Nieto. El papel de las grandes empresas en la așistencia privada. Forbes México (Consultado el 29/05/18) Disponible en: https://www.forbes.com.mx/el-papel-de-las-grandes-empresas-en-la-asistencia-privada/ 